\title{
The Dynamics of Message Processing among the Young Generation: The Case of 1Malaysia
}

\author{
Mohd Yusof Hj. Abdullah \\ School of Media and Communication Studies \\ Universiti Kebangsaan Malaysia (The National University of Malaysia) \\ 43600 Bangi, Selangor, Malaysia \\ Tel: 60-19-380-1533 E-mail: myusof@ukm.my \\ Ali Salman \\ School of Media and Communication Studies \\ Universiti Kebangsaan Malaysia (The National University of Malaysia) \\ 43600 Bangi, Selangor, Malaysia
}

Tel: 60-19-612-6568Ｅ-mail: asalmanphd@gmail.com

Received: February 26, 2012

Accepted: March 13, 2012 Published: April 16, 2012

doi:10.5539/ass.v8n5p65

URL: http://dx.doi.org/10.5539/ass.v8n5p65

This project is funded by the Ministry of Science,Technology and Innovation (MOSTI) Malaysia under the research code: UKM-SK-05-FRGS0067-2010

\begin{abstract}
Communication campaign is a social apparatus to educate the public. It aims to inform, persuade and/or motivate attitude change among the target audiences on issues, problems or innovations. The concept of 1Malaysia is one of the recent innovations in the form of ideas introduced by the current government under the leadership of Dato' Seri Mohd Najib Tun Razak. Numerous forms of messages on 1Malaysia were formulated and disseminated over the media. This paper discusses message processing by the audiences on the concept of 1Malaysia. The discussion is based on a survey among 200 young generation studying in the Klang Valley areas. The study gauges their opinions on the meaning of 1Malaysia, their understanding, and probable actions taken after being exposed to the messages. The findings indicate that the exposure to the messages of 1Malaysia is rather high, indicating that they either read, see or listen to the messages in various media. The respondemts have somehow embraced the spirit of 1Malaysia in their inter ethnic relation and interaction. However, more programs or events are recommended to promote the values in 1Malaysia among the young generation.
\end{abstract}

Keywords: Message processing, Young generation, Communication campaign, 1Malaysia

\section{Introduction}

Message effectiveness in a campaign depends on information process factors which are found in every individual. The factors consist of motivation and the ability to process message. Personal motivation will increase base on the information in the campaign that convey similar information connected to the personality of the audience (Chun-Tuan Chang and Yu-Kang Lee, 2009). It means when audience feel that the campaign can profit them or is related to their interest, it will be easily accepted and practised. Apart from motivation, cognition aspect also takes into account the achievements from a particular campaign.

Target audience will possibly be processing message only at the first level namely exposure to the message or to second stage, exposure and understanding the message but do not take action. They could also actively process message, namely awareness, understanding, and use of the message or take action base on it. If target audience process message actively, the communication campaign will leave the effect intended by the campaign. When a particular reform is introduced into a social system, the objective would be to ensure widespread acceptance 
among the different levels of society. How can we ensure that the reform get widespread acceptance? Theory diffusion of innovation assumes that widespread acceptance of reform is the result from the process of diffusion of that particular reform. Diffusion process is widespread distribution of message through communication activity for the purpose of influencing the target group to use that reform (Rogers, 2003)

Frequently asked question is whether the effort carried out to communicate the reform is as effective as its impact on the attitude and components of the target audience. This requires us to study message processing process by the audiences in their response to the messages disseminated through campaign. Message processing is the tendency of the audience or message recipient to process message (Mazis and Staelin, 1982)

Message processing involves three levels and the first is exposure to the message. This can be gauged with readership pattern, listening, and viewership. Second is message interpretation and is regarding what is understood and known from that message. The third stage is message retention namely what is remembered and the extent to which the knowledge is used to take a particular action such as appreciating and practicing the core values in 1Malaysia.

\section{Message Processing in a Communication Campaign}

Some communication scholars state that internal individual factor and message factor motivate audience to process message. Internal individual factor depends on the extent the individual feels the issue is linked and relevant to his or her interest (Niederdeppe et al, 2008). Message factor on the other hand is linked to the extent to which the message is attractive, complete, easy, and convincing to the receiver. Yet, in this ever developing world, there is possibility of another factor which propels target audience, especially the young generation to process or not to process a message.

In disseminating information to the young generation, the use of new media is very crucial, as they use the new media extensively. This is similar to the survey results by Drotner (2000) which revealed that the young generation is in the front row in exploring the new media technology.

This study strives to understand the dynamic of message processing among the target audience of 1Malaysia campaign which is the young generation. This study looks into the reaction and response of the young generation towards 1Malaysia message which is communicated through the media. At the same time it also identifies the medium that is most effective to promote and inculcate1Malaysia spirit among the young generation. This study also seek to evaluate the levels of message processing among the young generation and at the same time, determine the relationship between and among the various message processing stages exposure, understanding and impact. Lastly, to compliment the understanding of message processing as an input in designing a campaign strategy.

Message is one of the signs which should be known by the recipient. Message may be needed to transact with "how" and " when" a knowledge can uphold behavioural change. In a communication campaign, the message becomes a very important element. Campaign should be devoted to supply useful and relevant information for a target group as it is important stimulant for behavioural change (Snyder, 2007).

To know the response towards a message, message processing by the audience must be observed. Message processing by audiences on messages received from the media depends on acceptance from the respective audience. In this matter audience age is influential in the acceptance and processing of the message received (Panwar and Aqnihotri, 2006). Apart from social norms, gender also can affect a person in processing message. Message processing is different for every audience based on age, gender, cognitive aspects and social environment (Panwar and Aqnihotri, 2006).

In addition, Smith and Bauman (2005) conducted a study to gauge whether the source of awareness about sun protection campaign in New South Wales, Australia is associated with message recall and knowledge about sun protection and various behaviours. The study measured the retention of the campaign, awareness of the source of the campaign message, knowledge about sun protection, attitude and behaviour, and demographic features of the respondents.

Several studies conducted correlated communication campaign, message delivery and the message adoption process. Among the studies are conducted by Samsudin A Rahim and Latiffah Pawanteh (2002) and Pawanteh (2007). Their study entitled "study of healthy lifestyle campaign assessment aim to observe series of impact which has already been executed by the Ministry of Health of Malaysia since 1991. This study found out that catering to information demand was important because information seeking by individuals on healthy lifestyle was the early signs of the importance of practicing healthy lifestyle. 
In another study, White, Tan, Wakafield and Hill (2003) examined awareness and youth reaction on anti smoking campaign. By using survey method, questionnaires were sent to 400 respondetnts aged between 14-17years all over Australia. Their findings showed that some $85 \%$ agreed that the campaign is in keeping with them while $53 \%$ found out the campaign motivate them to be able to stop smoking.

\section{Methodoloy}

This study used survey to obtain data. The survey was conducted on 200 respondents from three locations in the Klang Valley namely in the areas of Cheras, Petaling Jaya and Ampang. The respondents, who are between 15 and 30 years of age, were randomly chosen for the study. They comprised of Malays $(49.5 \%)$, Chinese (30\%) and Indians $(20 \%)$. The percentage composition of the three main ethnics was taken into consideration during data collection so that the data will be representative.

Questions that were used in this study are combination of open and closed ended questions. This means some of the responses given by the respondents were recorded in blank spaces that are provided.

SPSS 20.0 was used to analyse the data. The data were analysed using descriptive and inferential statistics.

\section{Results}

\subsection{Descriptive data}

Demographically, the respondents consist of $50.5 \%$ male and $49.5 \%$ female (Table 1). Exposure to messages on 1 Malaysia was measured by the indicators of what they hear, see, listen and read. Some $88 \%$ of the respondents said they were exposed to 1Malaysia messages. Television was the main channel of exposure with $97 \%$ of the respondents being expose to the message by television. This is followed by the newspaper (84\%), social media $(76 \%)$, peers $(69 \%)$, community programmes $(62 \%)$, radio $(61 \%)$ and blog $(49 \%)$.

Knowledge on 1Malaysia (Table 2) is measured on what they know about 1Malaysia, who introduced the concept and the values in 1 Malaysia. Some $43 \%$ said they knew when 1 Malaysia was introduced, while $25 \%$ said they were not sure. More than two thirds $(71 \%)$ of the respondents said they knew who introduced 1Malaysia. However, their knowledge on the values and core meanings of 1Malaysia is still low $(29 \%)$. One third $(33.5 \%)$ of the respondents said that 1Malaysia is a different concept from Malaysian Malaysia. Only $26.5 \%$ think that the concept is not clear and not relevant for Malaysia, while 35\% think it is relevant. Some 37.5\% said they were not sure.

In terms of understanding (Table 3 ) the message, $66 \%$ of the respondents said it is easy to understand. Some $36.5 \%$ said they understand the core elements of 1 Malaysia such as acceptance, nationhood and social justice. Only $26 \%$ said they understand the values in 1Malaysia.

Concerning the outcomes or impact (Table 4) of their exposure and understanding of 1Malaysia messages, $77 \%$ feel that this will prevent them from doing things that will create disharmony among the ethnics. Some $45 \%$ said that they will join any programs of activities participated by all the ethnics and $49 \%$ show interest in joining 1Malaysia programs. One third of the respondents (35.2\%) said they are members of association related to 1Malaysia. Some $72 \%$ said 1 Malaysia has taught them to be more tolerant towards other ethnics, while $74 \%$ also said they will improve their relation and engagement with other ethnic. About two thirds $(67 \%)$ of the respondents said 1Malaysia messages have increased their love for the country. Only 19\% said that 1Malaysia messages have not affected their lives. In other words, the message has not made an impact on their lives.

\subsection{Inferential Data: Relationship of the various stages of message processing}

The Guildford's Rule of Thumb is used for the interpretation of the Pearson correlation strengths where if $r$ is: 0.0-0.29 (negligible or little correlation); 0.3-0.49 (Low Correlation); 0.5-0.69 (Moderate or Marked Correlation); 0.7-0.89 (High Correlation); 0.9-1.00 (Very High Correlation). Prior to running the correlation statistics, the means of the variables were computed and thus the computed means were derived as in Table 5 together with the standard deviations.

Based on the Guildford's Rule of Thumb, from the two-tailed correlation analysis (Table 6), there was a positive and significant relationship among the three main variables viz. exposure (knowledge), understanding and impact.

Understanding $(\mathrm{r}=.781)$ and impact $(\mathrm{r}=.687)$ both have a high and marked correlations respectively with exposure. Whereas impact $(\mathrm{r}=.754)$ has a high correlation with understanding. Thus the higher the exposure to One 1Malaysia messages, the higher the understanding and impact, likewise the higher the understanding, the higher the impact. 


\section{Discussions and Conclusion}

Since the inception of 1Malaysia in 2008, various forms of messages were designed and disseminated. Media such as $\mathrm{TV}$, radio, newspaper and Internet were utilized to convey the messages for public consumption. The continuous portrayal of 1Malaysia has impacted the views of the public. From the message processing perspective, the public has been exposed to the messages either through reading, viewing or listening.

To realise this objective, media play important role to convey information on 1 Malaysia. Media diversity such as print media, electronic and new media help to make the message effective. In fact, the people also have been given opportunity to put forward direct opinion on website or columns in newspapers. Two-way communication was the main element which reflects effectiveness of a message based on response from audience. Therefore, wise government requires to diversify media use. Delivery which is too formal is difficult to attract teenagers and youth.

The Prime Minister's concept of 1Malaysia sounds good. Under this concept the meaning is that Malaysians stand, think and act as one Malaysian race or people. And Malaysians take action base on the will of all the ethnic groups in the country (Booklet 1Malaysia, 2009). This means that every race in Malaysia has to think about and act beyond respective ethnic interest.

From the findings of this study, Malaysian society in general knows and understands the concept of 1Malaysia. They continue to give an encouraging response to the concept. Two-third of the respondents knows who introduced 1Malaysia and half knows when it was introduced.

From the results, the behavioural change and thinking after processing 1 Malaysia message shows that the audiences have understood and given encouraging response towards this campaign. It can be said that the message that was conveyed is accepted, understood and retained by the audience and it has made an impact on their inter-ethnic relationship. This is congruent to a study by White, Tan, Wakafield and Hill (2003) where more than two-thirds of of the intended audience said that the anti-smoking campaign is in keeping with them while more than half found out the campaign motivate them to be able to stop smoking.

The relationship between and among the stages or main variables of the message processing in the 1Malaysia campaign is highly significant indicating the influence they have on one another. Thus the higher the exposure to 1Malaysia messages, the higher the understanding and impact, likewise the higher the understanding, the higher the impact.

This implies that for an effective communication campaign, the stages in message processing, the exposure and understaning in particular, should be designed in such a way that they compliment one another. Each of the stage needs to be effective or else the required result may not be achieved.

The study has successfully achieved the objectives set out at the onset of the study. The effectiveness of the campaign in championing the objectives of 1Malaysia can not still be determined yet because there are doubt and less trust among some audience. Hence, more effective ways should be applied with more frequency of message disemination and also the use of other methods. For example, the holding of outdoor activities that can add value and unity among the multiracial society.

Despite the fact that there still exist some pockets or areas of misunderstandings among the ethnics, the authors are still positive on the future relationship as they still live in same neighbourhood and work together in same offices. Hence this relationship gap needs to be continuously improved and 1Malaysia campaign, through a well designed message, will continue to play a very important role in improving the relationship and understanding of all the ethnics.

\section{References}

Booklet 1 Malaysia. (2009). 1 Malaysia rakyat didahulukan pencapaian diutamakan. Retrieved 25 Oktober, 2010, from: http://www.kpkk.gov.my/pdf/Booklet_1Malaysia.pdf

Chun-Tuan Chang \& Yu-Kang Lee. (2009). Framing Charity Advertising: Influences of Message Framing, Image Valence, and Temporal Framing on a Charitable Appeal. Journal of Applied Social Psychology, 39(12): 2910-2935. http://dx.doi.org/10.1111/j.1559-1816.2009.00555.x

Drotner, K. (2000). Difference and Diversity: trends in young Danes media uses. Jurnal Media, Culture and Society, 22(2).

Mazis, M. B. \& Staelin, R. (1982). Using Information-Processing Principles in Public Policymaking. Journal of Marketing \& Public Policy, Vol. 1, pp. 3-14. 
Niederdeppe, J., Lisa bu, Q., Borah, P., Kindig, D. A. \& Robert, S. A. (2008). Message Design Strategies to Raise Public Awareness of social Determinants of Health and Population Health Disparities. The Milbank Quarterly, 86(3): 481-513. http://dx.doi.org/10.1111/j.1468-0009.2008.00530.x

Panwar, J, S. \& Aqnihotri, M. (2006). Advertising Message Processing Amongs Urban Children An Indian Experience With Special Reference To TV Advertising. Journal of Marketing And Logistic, 18(4): $303-327$. http://dx.doi.org/10.1108/13555850610703263

Pawanteh, L. (2007). Komunikasi dalam masyarakat majmuk di Malaysia. In Samsudin A. Rahim \& Mohd Safar Hasim. (pngr.). Industri Komunikasi di Malaysia, hlm (191-205). Selangor: Universiti Kebangsaan Malaysia.

Rogers, E.M. (2003). Diffusion of innovations (5 ${ }^{\text {th }}$ ed.). New York: Free Press.

Samsudin A Rahim \& Latiffah Pawanteh. (2002). Kajian penialain kempen hidup sihat. Bangi: Universiti Kebangsaan Malaysia.

Smith, B.J \& Bauman, A.E. (2005). Awareness of message source and its association with the impacts of sun protection campaign in Australia. Journal of Health Education, Vol. 105, No. 1, $42-52$. http://dx.doi.org/10.1108/09654280510572295

Snyder, L.B. (2007). Health communication campaign and their impact on behavior. Journal of Nutrition Education and Behavior, Vol. 39, No. 25, 32-40. http://dx.doi.org/10.1016/j.jneb.2006.09.004

White, V., Tan, N., Wakefield, M. \& Hill, D. (2003). Do adult focused anti-smoking campaigns have an impact on adolescents? The case of the Australian national tobacco campaign. Tobacco Control, 12, ii23-ii29. http://dx.doi.org/10.1136/tc.12.suppl_2.ii23

Table 1. Channels of Exposure to 1Malaysia Messages $(n=200)$

\begin{tabular}{ll}
\hline Channel & $\%$ \\
\hline Television & 97 \\
Newspaper & 84 \\
Social Media & 76 \\
Peers & 69 \\
Community Programes & 62 \\
Radio & 61 \\
Blog & 49 \\
\hline
\end{tabular}

Table 2. Knowledge of 1Malaysia $(n=200)$

$\%$

Know when 1Malaysia was introduced 43

Not sure when 1Malaysia was introduced

Know who introduced 1Malaysia

Knowledge on values, core meanings of 1Malaysia

Know that 1Malaysia is different from

Malaysian Malaysia

Think the concept not clear and not relevant for

\section{5}

or Malaysia

Think the concept is relevant. 35

Not sure if it is relevant 
Table 3. Understanding of 1 Malaysia Messages $(n=200)$

\begin{tabular}{ll}
\hline & $\%$ \\
Easy to understand & 66 \\
Understanding the Core Elements & 36.5 \\
Understanding the Values & 26 \\
\hline
\end{tabular}

Table 4. Outcome (Impact) of 1Malaysia Messages ( $\mathrm{n}=200$ )

$\%$

Prevent from creating disharmony among the ethnics 77

Will participate in activities by all ethnics

Shown interest in joining 1Malaysia Programs

Members of association related to 1Malaysia

Become more tolerant towards other ethnics

Ready to improve their relation and engagement with other ethnics 74

Increased their love for country

1Malaysia messages have not made an impact on their lives

Table 5. Computed Means of the Main Variables

\begin{tabular}{lll}
\hline Variables & Computed Mean & SD \\
\hline Exposure & 61.3 & 12.9 \\
Understanding & 76.0 & 13.1 \\
Impact & 60.6 & 9.9 \\
\end{tabular}

Table 6. Correlations of the main variables

\begin{tabular}{llll}
\hline & & Understanding & Impact \\
\hline Exposure & $\boldsymbol{r}$ & .781 & .687 \\
& $\boldsymbol{p}$ & .000 & .000 \\
Understanding $\boldsymbol{r}$ & & .754 \\
& $\boldsymbol{P}$ & - & .000 \\
\hline
\end{tabular}

Correlation is significant at the 0.01 level (2-tailed) 